\title{
SOCIALISMO E ECONOMIA SOLIDÁRIA NO SINDICALISMO DA CUT: UMA ANÁLISE DA CONCEPÇÃO CUTISTA A PARTIR DA INFLUÊNCIA DE PAUL SINGER
}

João Guilherme de Souza Corrêa ${ }^{1}$

RESUMO: A ideia de que a Central Única dos Trabalhadores (CUT) é uma entidade que se organiza na perspectiva da construção de uma sociedade socialista é tema nunca retirado do estatuto da entidade até hoje. Esse artigo faz uma análise da noção de socialismo para a CUT contemporaneamente a partir do seu engajamento em atividades da chamada economia solidária, mostrando a influência das teses de Paul Singer nelas, e relacionando-a com a prática do seu sindicalismo cidadão. Esperamos mostrar os limites da estratégia política guiada por essa noção para a tão anunciada transformação social.

PALAVRAS-CHAVE: Central Única dos Trabalhadores. Socialismo. Economia Solidária.

ABSTRACT: The idea that the Central Única dos Trabalhadores (CUT) is an entity that is organized from the perspective of building a socialist society has been never removed from the entity's status until today. This article is an analysis of the contemporary concept of socialism for the CUT from its engagement in activities of so-called solidarity economy, showing the influence of Paul Singer thesis on them, and relating it to practice of citizen's trade unionism. We aim to show the limits of political strategy guided by this concept for social transformation as announced.

KEYWORDS: Central Única dos Trabalhadores. Socialism. Solidarity Economy.

1 Professor Adjunto de Sociologia da Educação da Universidade Estadual do Paraná (UNESPAR) - campus Paranaguá. Doutor em Ciências Sociais. 


\section{Introdução}

O nascimento da Central Única dos Trabalhadores (CUT) no início dos anos 1980 foi o resultado da concatenação das lutas políticas e sindicais que explodiram no fim dos anos 1970 em regiões brasileiras de maior concentração industrial, mas mais notadamente no ABC paulista. A sua formação se deu por um coletivo de tendências políticas diversas que tinham por objetivo direto reorganizar o movimento sindical brasileiro, lutando imediatamente contra o arrocho salarial e a superexploração do trabalho, mas na perspectiva de realizar o socialismo, que era anunciado inicialmente como um dos objetivos históricos da nova entidade. Pode-se ler nas resoluções do seu primeiro congresso (I CONCUT) a noção de que a entidade já deveria propor intervenções em nível nacional na "perspectiva de construção de uma sociedade socialista" (CUT, 1984).

Mesmo que a palavra socialismo não tenha aparecido expressamente no seu primeiro estatuto de 1984 como horizonte fundamental da Central, as lutas empreendidas, as formas como elas eram tocadas e as palavras do vocabulário militante não deixavam dúvidas de que a CUT estava na esteira das práticas que comumente identificam-se como sendo recorrentes no exercício político das esquerdas, e, sobretudo, das esquerdas socialistas. É interessante observar que mesmo que a agitação da Central durante seu período fundacional tenha sido inegavelmente marcada por uma perspectiva anticapitalista e antiliberal, a definição do socialismo como um dos fundamentos do sindicalismo cutista não era "garantida documentalmente". Foi no seu segundo congresso em 1986 - o II CONCUT - que ocorreu a proclamação da palavra socialismo pela primeira vez no seu estatuto. Embora os estatutos da central tenham sido recorrentemente alterados em seus congressos posteriores, a ideia de que ela é uma entidade que deveria atuar na direção de uma transformação socialista na sociedade brasileira permanece assegurada estatutariamente ainda hoje como estratégia da Central. 
Entretanto, sabe-se que não é a existência do termo socialismo nos estatutos da entidade que nos permite caracterizála como uma entidade que executa práticas concretas na intenção de construir essa proposta de sistema político-econômico. Embora a opção de adotar a palavra socialismo nas suas resoluções significasse, antes de tudo, uma marca de separação das práticas políticas do sindicalismo pelego e, ao mesmo tempo, simbolizasse seu distanciamento ideológico da Central Geral dos Trabalhadores (CGT), fundada na mesma época e com perfil moderado, a escolha pela utilização do termo procurava também fixar a natureza classista e operária que ensejou a sua fundação. Assim, uma vez garantida uma inspiração socialista (ainda que genérica) para a luta, ficou a cargo da disputa política interna a delimitação desse sentido socialista na CUT.

Deste modo, com a supremacia política exercida por suas correntes reformistas, a atuação da entidade "em direção ao socialismo" passou a estar associada com uma espécie de luta pela efetivação da cidadania (entendida como universalização de direitos, de serviços sociais e de emprego) e, na virada do milênio, a associação dessa interpretação com a construção de alternativas econômicas ao modelo de capitalismo vigente no Brasil através do apoio ao modelo de desenvolvimento levado adiante pelo governo federal comandado pelo Partido dos Trabalhadores (PT), escorado na ampliação do investimento estatal, no fortalecimento do mercado interno, sobretudo dos mais pobres, através de crédito subsidiado, mas no apoio ao cooperativismo e à economia solidária também.

A economia solidária, como parte da estratégia de intervenção política no sentido de fazer a transformação social, começou a ganhar corpo no interior da entidade a partir de meados da década de 1990 com a ativa participação de sindicalistas cutistas nos processos de recuperação de fábricas falidas no país, mas especialmente em São Paulo. A presença da CUT no movimento das fábricas recuperadas aglutinadas na ANTEAG (Associação Nacional de Trabalhadores em Empresas de Autogestão e Participação Acionária) levou os dirigentes da Central a 
disputarem em Conselhos na estrutura do Estado os orçamentos de programas governamentais disponíveis para propostas de combate ao desemprego, tentando, com isso, destinar esses recursos públicos para as iniciativas com caráter cooperativo que se desenvolviam na sua base. A participação nas instâncias deliberativas dos recursos do Fundo de Amparo ao Trabalhador (FAT) foi o ponto inaugural desse momento, pois foi quando a Central conseguiu obter recursos para a realização de cursos de capacitação para formar conselheiros para as comissões locais do FAT e para a formação de formadores em educação profissional. A partir do seu envolvimento direto no oferecimento de cursos de formação e profissionalização, a Central passou a investir também em cursos de qualificação para militantes envolvidos com fábricas recuperadas e cooperativas de diversos tipos.

A participação da CUT no movimento das fábricas recuperadas e no oferecimento dos cursos de formação e qualificação representou o encontro do seu sindicalismo com o cooperativismo e, na sequência, a conversão da sua proposta de socialismo em luta em defesa da efetivação de uma economia solidária.

Para continuarmos, é preciso estabelecer o que é economia solidária a partir do que existe de pacificado sobre o assunto. Para a maior parte dos seus militantes, ela se configura como sendo formada por empreendimentos econômicos alternativos de sobrevivência para grupos sociais em situação de desemprego ou precariedade salarial e de renda, realizados sob a forma de cooperativas, empresas autogestionadas, associações e complexos cooperativos que, em tese, atuariam à margem da economia de mercado. Todavia, para que estes ainda se definam como realizações concernentes à economia solidária é preciso que eles se caracterizem como sendo atividades econômicas marcadas pela cooperação, pela autogestão, pela viabilidade econômica e pela solidariedade (BRASIL. Ministério do Trabalho e Emprego, 2006). Mesmo nessa delimitada perspectiva, uma grande quantidade de práticas diferenciadas é enquadrada sob o domínio da economia solidária: trabalhadores que constroem suas casas por meio de mutirão, uma pequena cooperativa de 
artesãos ou uma grande empresa cooperativa, clubes de trocas, banco de crédito cooperativo, fábricas falidas e que foram recuperadas pelos trabalhadores, associações de diversos tipos, microempresas geridas coletivamente, etc.

A partir dessa caracterização não seria exagero dizer, em outros termos, que as atividades que caracterizam a economia solidária são as respostas que os trabalhadores precarizados e/ ou desempregados são forçados a buscarem (autonomamente ou com auxílio de outras entidades, como igrejas, sindicatos, movimentos sociais ou o próprio Estado), fora da opção do assalariamento formal, para tentarem mitigar sua situação de pobreza num cenário de recessão econômica. Essas práticas nasceram, não por iniciativa ideológica, mas porque os seus sujeitos foram empurrados a elas como uma alternativa de garantir as condições materiais de existência. Posteriormente é que se "descobriram" os valores solidários que os motivava ou apareceram a teorização e a politização sobre eles. Contudo, apesar da característica assistencialista que marca boa parte dessas ações, na maioria dos discursos que as defendem, aparece a ideia de que as experiências em economia solidária seriam "embriões de novas formas de organização da economia e da sociedade" (DOMINGUES; TEIXEIRA, 2007) e até mesmo o novo modo de produção socialista (SINGER, 2002).

A vinculação entre esta última noção e a concepção de socialismo da CUT e a sua problematização é o objetivo deste artigo.

\section{A base teórica da economia solidária na CUT: a contribuição de Paul Singer}

A construção do conceito de economia solidária no interior da CUT contou com a colaboração de diversos militantes e pesquisadores na área. O segmento destacado da CUT responsável por desenvolver sua política para a economia solidária promoveu diversas discussões teóricas para chegar a orientação predominante que guiaria a fundação de uma agência 
(a ADS - Agência de Desenvolvimento Solidário) que executaria as ações neste campo e o caminho político-ideológico que guiaria essas ações dali em diante. O Grupo de Trabalho montado pela CUT e liderado por Reginaldo Magalhães e Remígio Todeschini conseguiu sintetizar as discussões desse período que antecedeu a fundação da ADS sob a forma de um documento que ainda hoje é referência central para se entender o projeto da CUT para o tema.

O documento publicado pela CUT em 1999 e intitulado Sindicalismo e economia solidária: reflexões sobre o projeto da CUT, além de ter apresentado as motivações da realidade objetiva que conduziram a Central por este caminho, de ter historiado o caminho percorrido no interior da entidade até chegar à formulação da ideia de construção da ADS e de ter colocado questões políticas que precisariam ser levadas em conta para a efetivação do projeto, trouxe também as reflexões de importantes pesquisadores que militavam no assunto. Para formatar uma visão própria de economia solidária para a CUT, o referido documento apresentou os principais elementos das teorias de investigadores referencias no assunto, como Luiz Inácio Gaiger, Fernando Haddad e Paul Singer.

Embora Luiz Inácio Gaiger seja um dos precursores do estudo em economia solidária no Brasil e uns dos seus principais teóricos e Fernando Haddad tenha dado algumas contribuições significativas para a produção de conhecimento na área em meados dos anos 1990, Paul Singer é o principal emblema da economia solidária para a CUT e para o Brasil.

Militante socialista e sionista durante a sua juventude nas décadas de 1940 e 1950, ele chegou a participar da construção de um kibutz experimental na cidade de São Paulo. Além disso, Singer trabalhou como metalúrgico e foi um dos principais líderes da greve 300 mil que ocorreu em São Paulo em 1953. Estudou economia na USP a partir de 1956, onde também lecionou e obteve o título de doutor em Sociologia em 1966. Aposentado compulsoriamente pelo regime militar em 1969, Singer, não se exilou nem foi para a clandestinidade - com muitos de seus contemporâneos na universidade - mas permaneceu no Brasil, e, 
com a ajuda de outros professores, como José Arthur Gianotti e Fernando Henrique Cardoso, fundou o CEBRAP (Centro Brasileiro de Análise e Planejamento). No período em que participou do CEBRAP como economista (1969-1988), Singer voltou a lecionar, só que dessa vez na PUC de São Paulo. Esse período é marcado por importantes contribuições acadêmicas suas para a compreensão da realidade social e econômica do país. Ele foi ainda fundador do PT, membro de sua primeira executiva nacional e um dos assessores de primeira hora da CUT.

Além da importante biografia política e acadêmica que o credenciam ao posto de referência nacional no tema, consideramos também, como Germer (2006), que Singer se destaca nesse meio intelectual por tentar teorizar a economia solidária a partir de alguns elementos da teoria marxista, mesmo que a despeito de certa precisão explicativa já consagrada pela aplicação dos conceitos.

Pensando a realidade social brasileira na intenção de propor respostas para problemas concretos da mesma e apoiando-se em referências marxistas (mas fugindo também de esquematismos simplistas que marcaram parcela da militância comunista no Brasil), Singer empreende um esforço teórico de revisitar a história da organização dos trabalhadores em busca de um projeto próprio de sociedade, enxergando no cooperativismo do século XIX a economia solidária que marcaria essa busca hoje em dia.

Antes de avançar é preciso informar que não é o objetivo aqui passar a limpo toda a produção teórica de Singer. O que nos propomos fazer a seguir é colocar em questionamento algumas das teses centrais desse autor trabalhadas em textos relativamente recentes e que servem aos propósitos de defesa da economia solidária para a prática da CUT.

Sendo assim, ainda que Singer tenha produzido academicamente e militantemente desde os anos 1960, é somente a partir de meados dos anos 1990 que o temário da economia solidária começa a se assentar explicitamente na sua bibliografia, apesar de dizer que escrevia sobre o tema, mas sem saber que ele tinha esse nome. Uma obra referencial que 
fundamentou posteriormente as suas teses sobre economia solidária é o livro Uma utopia militante: repensando o socialismo (de 1998). Nela, Singer se propõe a rediscutir o socialismo a partir das experiências fracassadas da União Soviética e do "socialismo real". Segundo ele, a falha na tentativa de construir o socialismo a partir do planejamento centralizado e estatização dos meios de produção fez com que necessário fosse revitalizar a ideia de que seria possível alcançar o "modo de produção" socialista a partir dos interstícios da "formação social" capitalista. Neste último conceito está colocado um dos argumentos centrais das teses de Singer. De acordo com ele, uma determinada "formação social2" comportaria uma quantidade diferentes de "modos de produção". Assim, a formação social em que vivemos nos últimos duzentos anos é capitalista porque o modo de produção predominante nela é o capitalista. Nesse sentido, o modo de produção capitalista se caracterizaria pela produção em empresas privadas, onde os proprietários comandam a produção objetivando o lucro. Os outros modos de produção na formação social capitalista seriam a produção simples de mercadorias (produtores independentes e donos dos meios de produção), a produção pública (estatal ou privada que oferece serviços gratuitamente), e a produção cooperativa (empresas que seriam propriedade dos trabalhadores) (SINGER, 1999, p. 137-138).

De acordo com o autor, os modos de produção operariam de maneira concomitante, trocando produtos entre si e também competindo. É a soma desses distintos modos de produção que formariam a infraestrutura da formação social (uma ideia que ele toma emprestado de Marx). Um desdobramento importante dessas teses diz respeito ao fato que as transformações sociais, da passagem de uma formação social para outra, da hegemonização de um determinado modo de produção sobre os outros, se daria a partir de revoluções sociais, não de revoluções políticas, como, segundo seu ponto de vista, preconizaria o marxismo considerado tradicional.

2 Em Marx, a expressão "formação social" foi utilizada no famoso "Prefácio" como sendo somente sinônimo de sociedade (MARX, 2005). 
Analisando a história do capitalismo a partir dessa ótica, Singer descreve que o modo de produção capitalista teria tido sua origem nos poros de outros modos de produção dominantes (do servil na Europa e no Japão, do escravista nas Américas e dos tributários na Ásia). Preocupado, sobretudo, com a constituição do capitalismo na Europa ocidental, particularmente na Inglaterra, Singer vai dizer que os monopólios criados pelas corporações de mestres provocaram o aparecimento de um grande número de pobres, marginalizados do tipo de produção dominante, que enxergaram numa espécie de assalariamento clandestino a única alternativa de sobrevivência. Com o passar do tempo, diz ele, os prejudicados pelo monopólio constituíram uma parcela significativa da sociedade, que, descontente com tal sistema, passou a se manifestar contrariamente a ele. Entretanto, diz ele:

Os que passaram a se rebelar contra o regime dos monopólios não eram todos empresários capitalistas; junto a eles encontravam-se artesãos, mercadores, camponeses, terratenentes e trabalhadores assalariados e por conta própria. (SINGER, 1999, p. 30).

Porém, ainda segundo o autor, a burguesia capitalista era o grupo social portador da proposta capaz de, em princípio, atender aos interesses dos descontentes. Assim foi que o modo de produção capitalista se tornou majoritário dentro do feudalismo. A revolução industrial veio depois para completar a revolução capitalista que já havia se iniciado algum tempo antes e que continua se desenrolando sem cessar desde então (SINGER, 1999).

Usando do mesmo paradigma, Singer se coloca a analisar também o que ele denomina de "revolução social socialista". Essa revolução social teria nascido junto com a revolução social capitalista a partir das lutas de resistência da classe operária aos avanços do modo de produção capitalista. Essa resistência teria se dado basicamente de três formas: a) oposição ao industrialismo em si, em nome dos direitos adquiridos e dos fundamentos do antigo regime; b) somando-se à luta pela democracia; c) desenvolvimento 
de formas próprias, potencialmente anticapitalistas, como o sindicalismo e o cooperativismo (SINGER, 1999, p. 68).

$E$ são justamente dessas últimas formas de resistência (sindicalismo e cooperativismo) que Singer se utiliza para pensar a superação da formação social capitalista pela formação social socialista, onde predominaria o modo de produção socialista. Nesse sentido, um dos argumentos mais persistentes de Singer sobre a necessidade de se construir cooperativas no capitalismo contemporâneo ou, mais genericamente falando, empreendimentos de economia solidária (como o próprio Singer retificou), assenta-se na importância histórica que eles tiveram na conquista de êxitos para a classe trabalhadora desde o início do capitalismo industrial. Para o nosso autor, as cooperativas e a economia solidária seriam "implantes" típicos do modo de produção socialista dentro da formação e do modo de produção dominante, o capitalista, e que, se fomentados, poderiam levar à transição (lenta e sem violência) para essa nova sociedade.

Para Singer, o movimento cooperativista do início da industrialização e o sindicalismo nascente teriam sido movimentos semelhantes desde o seu começo. "A interconexão ideológica e organizacional de sindicatos e cooperativas operárias era muito forte" (SINGER, 1999, p. 93), mas principalmente entre as décadas de 20 e 30 do século XIX. Contudo, teria sido mais forte a influência dos ideais cooperativos (especialmente os do célebre socialista utópico Robert Owen) sobre o movimento sindical do que o contrário, fazendo com que este se apropriasse e reinterpretasse os ideais daquele. Nesse ínterim, para Singer, a luta econômica dos trabalhadores (como a sua organização sob a forma cooperativista) teria tido a primazia na conformação de suas estratégias de resistência ao modo de produção capitalista em detrimento da luta política, que, por sua vez, estava subordinado à primeira. Interpretamos nas teses de Singer que a própria origem dos sindicatos estaria relacionada, de certa forma, ao cooperativismo, posto que essa forma de união política teria nascido de demandas econômicas. Segundo o autor, a organização dos trabalhadores qualificados para oferecer a sua 
força de trabalho sob a forma de monopólio foi vital para enfrentar o poder econômico dos empregadores, à maneira como as cooperativas propriamente ditas fizeram depois.

É na esteira dessas reflexões que Singer vai se dedicar a compreender a importância do cooperativismo na construção do socialismo por dentro das entranhas do capitalismo já a partir das primeiras décadas do século XIX. Para tanto, ele elege as ideias de Robert Owen como a representação máxima da construção do novo modo de produção responsável pela revolução social.

Em breve descrição, Robert Owen (1771-1858) ${ }^{3}$ foi um industrial galês que fez funcionar entre 1800 e 1824 em Glasgow, na Escócia, o complexo têxtil New Lanark, onde implantou benfeitorias completamente inovadoras para a época, como casas confortáveis para trabalhadores, escolas para os seus filhos, a impedição do trabalho infantil antes dos dez anos de idade, a proibição de castigos físicos aos operários, a redução da jornada de trabalho e a criação de armazéns que forneciam alimentos e outras mercadorias a preço de custo. Por esse meio, Owen tentava mostrar que o lucro e a prosperidade econômica como um todo não teriam que necessariamente se dar em cima de péssimas condições de trabalho e de vida. Seria possível manter negócios e ao mesmo tempo pagar bons salários e dar

3 Para a biografia de Owen, consultamos: Engels (1986); Heilbroner (1996); Hobsbawm (1983); Sandroni (1999); Singer (1999); Singer (2002); Teixeira (2002). Owen entrou para o rol dos considerados socialistas utópicos a partir do Manifesto Comunista (1847/1848), em que Marx e Engels classificaram as suas ideias e as suas práticas, assim como as de Saint-Simon e de Charles Fourier, como típicas do período incipiente da luta do proletariado contra a burguesia. As ideias dele foram valorizadas pelos dois revolucionários por terem sido as primeiras formas de questionamento do modo de produção capitalista, porém criticadas pela sua impotência em provocar a sua transformação, dada, principalmente, pela não identificação do proletariado como sujeito histórico dessa transformação. Engels voltou os olhos para Owen novamente quando escreveu seu famoso opúsculo Do socialismo utópico ao socialismo científico (1880), onde relatou a importância e os limites das lutas e das concepções socialistas (de Owen incluídas, claro) que antecederam a criação do materialismo histórico dialético e a proposta científica para a revolução proletária. 
boas condições de vida aos trabalhadores. Em 1825 ele mudou-se para o continente americano onde tentou criar, no México e nos EUA, colônias cooperativas (denominadas New Harmony) onde os pobres poderiam tornar-se produtores de riqueza em um ambiente socialmente favorável. Os experimentos em terras americanas não vingaram, então ele retornou à Inglaterra onde tentou restabelecer a sua ideia de fundar aldeias cooperativas. Criou em Hampshire, em 1832, unidades de produção cooperativa industrial e agrícola que tentaram abolir as transações intermediadas por dinheiro, mas fracassou novamente. Entretanto, as ideias de Owen inspiraram parcela significativa do movimento cooperativa da metade do século, especialmente na criação da cooperativa de consumo Society of Equitable Pionners (Sociedade dos Pioneiros Equitativos) em Rochdale, em 1844, considerada a "mãe" das cooperativas. A cooperativa de Rochdale foi fundada com uma significativa parcela de operários que seguiam os princípios owenistas e se tornou a principal referência para o movimento cooperativo mundial desde essa época até os dias de hoje, inspirando explicitamente os princípios da Aliança Cooperativa Internacional $(\mathrm{ACl})$, entidade de representação mundial do movimento, fundada em 1895 e que, no Brasil, tem como filiadas, tanto a Organização das Cooperativas do Brasil (OCB), quanto a UNISOL/Brasil (entidade vinculada à CUT e que tenta ser uma alternativa de esquerda à primeira).

Os princípios da cooperativa de Rochdale foram estabelecidos sob a forma de estatuto, reunindo em um único documento diversas regras que já haviam sido tentadas em outras iniciativas. De acordo com Schneider (1999), elas podem ser assim sintetizadas: democracia (expresso pela máxima "um homem, um voto"), livre adesão, livre saída, compras e vendas à vista, juro limitado ao capital de retorno, operações com não associados, aperfeiçoamento intelectual dos associados e devolução desinteressada do ativo líquido. Segundo esse autor, a ACI nasceu declaradamente inspirada nos ideais de Rochdale, porém, com as mudanças econômicas que o capitalismo do século XX atravessou, principalmente após a década de 1960, 
esses princípios foram revistos (ou se tornaram uma inspiração apenas) a fim de que as cooperativas pudessem se adaptar aos novos tempos de concorrência econômica (SCHNEIDER, 1999). No entanto, apesar de a cooperativa de Rochdale ser considerada por Singer como exemplo de sucesso da forma de organização socialista contra as determinações capitalistas, ele mesmo admite que o empreendimento se tornou uma empresa capitalista que objetivava o lucro e que foi dominada por acionistas (SINGER, 1999, p. 104-105). E ele não vê contradição nisso, já que a garantia de uma democracia interna já seria o suficiente para assegurar o caráter socialista da cooperativa.

Como se vê, Singer busca dar uma nova interpretação desde a aurora da industrialização a respeito das lutas dos trabalhadores pelo socialismo. Ele vai buscar nas práticas dos operários das primeiras décadas de século XIX uma justificativa histórica para tentar provar, quase numa interpretação "imanentista", que haveria uma espécie de "espírito da história" ou uma "essência", desde a consolidação do modo de produção capitalista, que conduzisse todas as lutas dos trabalhadores no rumo progressivo do socialismo, tendo na economia solidária (representada nessa época pelo cooperativismo) a sua mais perfeita definição. Mesmo que ele só tenha usado o termo economia solidária duas vezes nessa obra que aqui estamos tomando como referência, em textos posteriores ele vai ratificar essas suas teses, porém, rebatizando com este nome tanto as primeiras lutas de resistência dos trabalhadores qualificados contra o industrialismo, quanto $o$ cooperativismo owenista do século XIX.

É verdade, porém, que na Inglaterra e na França na época compreendida entre a manufatura e a grande indústria, os movimentos cooperativistas (pré-owenianos, inclusive) e o incipiente movimento sindical travaram lutas paralelas em busca de benefícios para o nascente proletariado industrial. Ainda que o surgimento das primeiras organizações sindicais tenha se dado para proteger os privilégios de trabalhadores profissionais qualificados que estavam ameaçados pelo avanço da industrialização (e não para reivindicar melhorias para uma 
situação ruim), essas organizações tiveram o mérito de deixar como ensinamento para o proletariado moderno que a união política poderia servir de arma para enfrentar a força do capital. Exemplo disso foi que, por esse meio, esses trabalhadores conseguiram assegurar para si remunerações mais elevadas que a dos operários industriais não qualificados, bem como melhores níveis educacionais e culturais também.

Conjuntamente, as lutas políticas dos trabalhadores expressas, ou sob a forma de estabelecimentos de sindicatos, ou até mesmo de destruição de máquinas, o cooperativismo (principalmente o de consumo) também se desenvolveu na Inglaterra desde o final do século XVIII como manifestação da insatisfação operária contra as relações de produção dominantes.

Todavia, como nos relata Abendroth (1977), em função do pioneirismo inglês na industrialização, a contradição entre o poder econômico da burguesia ascendente e a proletarização operária da plebe foi a mais adiantada e evidente do cenário europeu. Isso fez com que nesse país a luta em favor de reformas eleitorais fosse mais exacerbada e mobilizasse tanto a burguesia industrial, desejosa de maior influência sobre as decisões políticas, quanto a classe operária. Essa pressão política de dupla origem acabou resultando, em 1824, na revogação das leis que proibiam o associativismo (as famosas Combination Acts, de 1799). Após a crise que acometeu a economia da época, em 1825, viu-se que, durante ela, os "trabalhadores, desde que dispusessem de organizações sindicais que funcionassem, tinham condição de defender pelo menos algumas das vantagens conquistadas no período conjuntural anterior de melhoria de seu padrão de vida" (ABENDROTH, 1977, p. 19).

Nesse contexto que cooperativismo e sindicalismo puderam se expandir conjuntamente, abrindo caminho para que, pela primeira vez na história do movimento operário, os sindicatos e as cooperativas - tendo sua existência garantida legalmente - pudessem se aliar na luta pela democratização política e na transformação econômica da sociedade de acordo com o socialismo cooperativista, que tinha em Owen a principal referência (ABENDROTH, 1977, p. 19). 
Aconteceu, contudo, que os ideais de Owen tentavam colocar a nova organização econômica da sociedade (as cooperativas acompanhadas de uma nova moralidade econômica) emparelhada com as instituições econômicas do capitalismo a fim de que aquelas, pouco a pouco, se impusessem a estas, transformando a ordem capitalista. Ideia essa muitíssimo similar às teses que Singer defende com a noção de "implantes socialistas". Se não, vejamos quando em Uma utopia... vai dizer sobre a encruzilhada histórica em que estamos diante do neoliberalismo:

Para além do neoliberalismo, pode-se vislumbrar transformações sistêmicas do capitalismo em gestação. Por enquanto, empresa capitalista e democracia são antípodas. Estamos diante de um dilema histórico: ou a liberdade do capital destrói a democracia ou esta penetra nas empresas e destrói a liberdade do capital. (SINGER, 1999, p. 182).

Para ele, assim como para Owen, de maneira lenta e gradual, os ideais de democracia, "solidariedade" e justiça social rivalizariam com o individualismo e o despotismo capitalista até suplantarem-no e transformarem-se nos pilares da nova sociedade socialista. Owen (como iluminista que era) agia deliberadamente na esperança de conquistar os empresários para o seu esquema porque acreditava que seria possível convencê-los da racionalidade e moralidade intrínseca das ideias do seu sistema cooperativo. A Singer, um homem do século $X X$, não se pode conceder a mesma ingenuidade de Owen. Ele acredita que o socialismo poderia ser alcançado como que através de um "contrabando" de valores e práticas socialistas por dentro do capitalismo, pelo estímulo às atividades econômicas (cooperativas e demais empreendimentos econômico-solidários) que produzissem mercadorias e serviços dentro de relações de produção democráticas e solidárias, e com auxílio de um Estado de tipo keynesiano para redistribuir o dinheiro dos empreendimentos que ganhassem mais. Isso leva-o a afirmar que a economia solidária se efetivaria quando alcançasse 
os mesmos níveis de eficiência na produção e distribuição de mercadoria que os da economia capitalista ${ }^{4}$ (SINGER, 2002, p. 121).

Contudo, retornando a discussão aos tempos de Owen, precisamos ressaltar que a força do sindicalismo dentro do movimento operário como um todo - em constante luta por melhores condições de trabalho e de vida - provocou a reação dos empresários industriais, levando-os a exigirem do Estado a cassação desse tipo de organização. Essa reação empresarial acabou provocando o esfacelamento das ideias e das práticas cooperativistas no meio do movimento sindical (ABENDROTH, 1977, p. 20). Apesar disso, resquícios da doutrina cooperativista oweniana sobreviveram na Inglaterra ainda nos anos 60 do século XIX. No entanto, segundo Hobsbawm (1983), nessas iniciativas, o sonho utópico de libertar o trabalho da exploração capitalista acabou diluindo-se na formação de cooperativas comerciais ou de produtores, dotadas apenas de capitais suficientes para manter vivos os seus associados, com obrigações morais em relação à sociedade e protegidas e encorajadas pelo poder público (HOBSBAWM, 1983, p. 65). Em outras palavras, se transformaram em inocentes atividades que não foram mais capazes de provocar as relações de poder dominantes.

Essa nova derrota fez com que o movimento trabalhista inglês passasse a compreender as limitações da luta econômica imediata para a conquista dos seus interesses e começasse a fazer reivindicações também na esfera política na esperança de garantir condições mais estáveis para a efetivação de mudanças sociais que poderiam atender suas demandas ${ }^{5}$. E, como lembra Coggiola

4 Quanto a essa afirmação, poderíamos nos perguntar se os mesmos níveis de eficiência na produção e distribuição de mercadorias que os da economia capitalista não pressuporiam, também, os mesmos níveis de contradição social e destruição ambiental.

5 O Cartismo foi um belo exemplo desse momento. Baseando-se na reivindicação ao Parlamento de seis pontos contidos em uma carta divulgada pela London Working Men's Association. Os pontos eram: 1) representação proporcional da população no parlamento e divisão equitativa dos círculos 
(2010), foi justamente um movimento político o responsável por ter conquistado a primeira grande vitória "sindical" da classe operária, a jornada de trabalho de dez horas (COGGIOLA, 2010, p. 19) ${ }^{6}$.

Embora as lutas no campo econômico também fossem lutas políticas, é comum entre historiadores do movimento operário europeu (com base nos testemunhos oculares e nas análises perspicazes de Marx e Engels, principalmente) que a partir de 1848 o proletariado apareceu na cena política como uma classe social independente, com reivindicações próprias e aspirando ao poder político. Todavia, apesar da força inicial do movimento de caráter mais político do operariado inglês dessa época, o evento que fez reativar a luta da classe operária inglesa está relacionado ao estabelecimento do ano de 1848 como marco do surgimento do proletariado enquanto classe, a Primavera dos Povos.

Os acontecimentos desse ano são tomados como referência para o entendimento das lutas políticas que se desenrolaram no mundo moderno e até hoje inspiram o sonho da revolução internacional dos movimentos socialistas. E não chega ser exagero dizer que foi a partir daí (ou com inspiração nas formas de lutas iniciadas nesse momento) que praticamente todas as melhorias nas condições de trabalho e vida dos trabalhadores começaram a ser conquistadas, desde direitos políticos, como também trabalhistas e sociais.

Marx, em um panfleto escrito para a ocasião da fundação da Associação Internacional dos Trabalhadores, em 1864, fez uma avaliação sobre a organização da classe trabalhadora e o

eleitorais; 2) renovação anual dos deputados; 3) "sufrágio universal" para homens com mais de vinte e um anos e residentes há mais de cem meses no mesmo distrito eleitoral; 4) abolição do voto censitário; 5) escrutínio secreto; 6) remuneração para deputados e ocorrência de sessões regulares no parlamento. Apesar da derrota do movimento em 1848, até 1867 quase todos os pontos foram incorporados pela legislação inglesa, com exceção do número 2 (SANDRONI, 1999; TEIXEIRA, 2002).

6 Marx e Engels lembram, no Manifesto Comunista, que os movimentos owenistas na Inglaterra se opuseram "violentamente a toda ação política da classe trabalhadora”, inclusive ao cartismo (MARX; ENGELS; 2002, p. 60). 
desenvolvimento do capitalismo desde as famosas explosões sociais e políticas de 1848. Na sua apreciação, tanto a redução da jornada de trabalho para dez horas diárias, quanto os experimentos cooperativistas inspirados em Owen, foram conquistas das mobilizações operárias contra "a economia política da propriedade", porém fazendo uma ressalva de que aqueles experimentos foram valorizados em exagero (MARX, 1977).

Entretanto, a despeito da positividade das experiências cooperativistas para o período, Marx destacou o outro lado delas, assim se exprimindo:

Ao mesmo tempo, a experiência do período decorrido entre $1848 \mathrm{e}$ 1864 provou acima de qualquer dúvida que, por melhor que seja em princípio, e por mais útil que seja na prática, o trabalho cooperativo, se mantido dentro do estreito círculo dos esforços casuais de operários isolados, jamais conseguirá deter o desenvolvimento em progressão geométrica do monopólio, libertar as massas, ou sequer aliviar de maneira perceptível o peso de sua miséria. É talvez por essa mesma razão que, aristocratas bem intencionados, portavozes filantrópicos da burguesia e até economistas penetrantes, passaram de repente a elogiar ad nauseam o mesmo sistema cooperativista de trabalho que tinham tentado em vão cortar no nascedouro, cognominando-o de utopia de sonhadores, ou denunciando-o como o sacrilégio de socialistas. (MARX, 1977, p. 319-320).

Acontece que, mesmo sem ignorar esse aspecto da história do movimento trabalhista europeu, Singer opta pelas principiantes experiências dos trabalhadores na resistência aos imperativos da produção capitalista como referência para justificar histórica e teoricamente o fomento ao cooperativismo e demais atividades alinhadas à economia solidária contemporaneamente. Apesar da inegável importância que tiveram, elas, no entanto, não passaram de experiências que, ou demonstraram ser extremamente limitadas para defender o trabalho da exploração do capital ou acabaram se transformando em linha auxiliar dessa exploração. 
Isso não significa que tampouco haja uma fórmula ou modelo a ser seguido pelos movimentos de trabalhadores na busca por igualdade social, pela distribuição da riqueza socialmente produzida, por liberdade individual, pelo fim da destruição ambiental, em suma, por uma sociedade socialista. É necessário que críticas às experiências históricas sejam feitas, inclusive para se possa avançar em novas reflexões e propostas na direção da mudança social, contudo, parece inacreditável ter que se retornar à "estaca zero" desse movimento e usá-lo como referência central para se pensar a construção do socialismo hoje. Contudo, foi isso o que ocorreu com a CUT quando ela resolveu assumir o fomento à economia solidária como uma de suas bandeiras.

\section{A economia solidária e o sindicalismo cidadão na CUT}

Pelo exposto, percebemos que um dos elementos centrais das teses de Singer concentra-se na ideia de que a história da resistência dos trabalhadores ao modo de produção capitalista nos últimos dois séculos tem sido, mesmo que não se soubesse disso antes, a história da construção do socialismo pela economia solidária, tendo na formação das primeiras cooperativas a "alma" desse projeto.

No entanto, como foi dito acima, na Grã-Bretanha as lutas sob a forma de associação cooperativa representaram inicialmente uma entre as principais práticas que conseguiram melhorar as condições materiais de vida e trabalho dos primeiros operários industriais, compartilhando já com a suas organizações políticas sindicais o papel de instituição transformadora. Além do mais, esse enfrentamento conjunto se concentrou principalmente entre as décadas de 20 e 30 do século XIX, sendo que, posteriormente, o movimento sindical e o cooperativismo tomaram caminhos diferentes. O primeiro deu ensejo à forma prioritária de organização da classe trabalhadora mundialmente, responsável pela efetivação de uma série de direitos (políticos, trabalhistas e sociais) e o outro se converteu, apesar dos pesares, em importante paliativo econômico para trabalhadores pauperizados quando realizado em 
pequena escala (posto que em grande escala o cooperativismo virou uma prática complementar ao capitalismo).

Assim foi que no contexto de definição de sua identidade política nos anos 1990, a CUT vai se preocupar com o tema do desemprego trazido pelos ajustes neoliberais utilizando as propostas de economia solidária que estavam sendo formuladas por Singer no período. As ideias de economia solidária de Singer serviram para dar a CUT uma justificativa que tivesse certo respaldo histórico e autoridade intelectual para explicar a sua adesão direta às práticas econômico-solidárias e mais indiretamente à modalidade de sindicalismo cidadão e filantrópico que compõe a imagem política da Central hoje em dia.

Umas das primeiras e mais evidentes marcas de como as teses de Singer se plasmaram nas formulações do projeto cutista para a economia solidária pode ser verificado nos textos de debates do Grupo de Trabalho que foi formado para pensar a proposta cutista e que antecedeu a assunção oficial da temática pela Central. Singer oferece a esse debate um pequeno escrito de sua fabricação intitulado Cooperativismo e sindicatos ${ }^{7}$, onde faz um pequeno compêndio das ideias principais já apresentadas em Uma utopia..., acrescentando, porém, algumas ponderações sobre as novas cooperativas que estavam se formando no Brasil dos anos 1990 a partir das falências de empresas. Posteriormente publicado dentro do livreto Sindicalismo e economia solidária: reflexões sobre o projeto da CUT (1999), lê-se nele que para Singer o cooperativismo nasce já no fim do século XVI, estando nessa época representado pelas corporações de ofício. De acordo com o escrito: "O cooperativismo nasceu na Inglaterra, no final do século XVI, quando teve início a revolução industrial. Os trabalhadores das manufaturas, na época, eram qualificados e possuíam associações de ofício que controlavam o exercício profissional" (SINGER, 1999, p. 24). De mais a mais, a tese de que

7 SEMINÁRIOS REGIONAIS DE ECONOMIA SOLIDÁRIA, [ca. 1999], São Paulo. Resumo da sistematização. São Paulo: Escola Sindical São Paulo (CUT), [ca. 1999]. 3 p. 
os "primeiros sindicatos" dos trabalhadores qualificados fossem, na verdade, mais próximos das cooperativas do que dos sindicatos propriamente ditos, já havia sido apresentada implicitamente também na sua Uma utopia....

Outro momento onde é possível ver o ponto de vista histórico de Singer sendo assumido pela CUT está nas resoluções do seu sétimo congresso (VII CONCUT), evento que oficializou a proposta da CUT para a economia solidária. Lá, podemos ler:

Cabe lembrar que o sindicalismo e o cooperativismo surgem de um mesmo movimento, no início da industrialização, quando os trabalhadores qualificados construíram os "clubes de ofícios" (sindicatos) para defender os interesses da profissão e as sociedades de consumo (cooperativas) com vistas a possibilitar o desenvolvimento de trabalho, renda e acesso a produtos mais adequados aos seus associados. (CUT, 2000, p. 33, grifos nossos).

Ou mais claramente ainda nas deliberações extraídas da sua 10ª Plenária (2002):

A economia solidária é um projeto histórico e autêntico da classe trabalhadora e está colocada no debate político, inserida num processo histórico de revolução social e de construção de uma economia socialista. São experiências que proporcionam aos trabalhadores um grande aprendizado: como assumir coletivamente a gestão de empreendimentos produtivos segundo princípios democráticos e igualitários. (CUT, 2002, p. 54, grifos nossos).

Mais importante, porém, que somente perceber a presença da releitura de Singer a respeito da história do movimento operário nas sistematizações iniciais da economia solidária na CUT é distinguir, nessa influência, o seu casamento com as concepções políticas mais ampliadas que a Central já vinha colocando em prática desde a segunda metade da década de 1990 e que estão conformadas nos preceitos do sindicalismo cidadão. 
Um dos princípios orientadores dessa modalidade de ação sindical é a disposição de fazer da representação sindical algo para além da luta por questões trabalhistas, ocupando os espaços institucionais da estrutura do Estado para tentar interferir nos grandes temas nacionais ou participar da criação de outros espaços públicos não estatais, fornecendo serviços sociais de maneira conjunta ao Estado e aos governos.

Se, num primeiro momento, a ascensão dos ideais de cidadania na Central estava relacionada, em última instância, às ações defensivas diante do impacto do desemprego, terceirizações e diversas formas de precarização do trabalho, num segundo momento elas passaram, de ação conjuntural defensiva para revisão ideológico-programática. A nova atitude sindical da CUT construída nesse momento buscou a "linha do menor esforço de participação e de não-confronto com a política (e cultura) do capital, renunciando-se à luta contra-hegemônica" (ALVES, 2006).

Para se ter uma ideia disso, atualmente a CUT participa em mais de 114 conselhos, comitês e comissões nacionais da estrutura do Estado com mais de 250 dirigentes cutistas. Como se sabe, em si mesma, a existência de tais espaços e a participação de entidades de trabalhadores neles não significa, de imediato, prejuízo às suas causas, nem vai de encontro ao que boa parte dos movimentos socialistas de trabalhadores exigiu ao longo da história. Acontece que, como já se disse, existem outros espaços de poder onde decisões fundamentais para o país são tomadas e que não contam com qualquer forma de controle democrático por parte dos trabalhadores.

Em larga medida, a noção por trás desse participacionismo cutista encontra respaldo senão nas teses de Singer que advogam a proposta de se alcançar a "revolução social" sem confrontar interesses dos capitalistas. Nesse sentido, a democracia nas decisões (tanto dos conselhos, quantos por dentro dos empreendimentos de economia solidária) seria encarada como parte dos "implantes socialistas" que contaminaria as demais relações sociais do capitalismo, transformando-o. É bem verdade que ele enfatiza mais o papel das cooperativas nesse sentido, 
mas não podemos deixar de notar que ainda na década de 1990 ele fez uma apreciação da participação dos trabalhadores na gestão de fundos como o FAT e do FGTS em sua Uma utopia... .

Uma outra importante contribuição de Singer para a economia solidária está relacionada à sua primeira intervenção pública a respeito do tema. Quando a expressão economia solidária foi utilizada pela primeira vez em um artigo publicado na Folha de São Paulo, de 11 de julho de 1996, Singer apresentou a proposta de que o poder público deveria criar um setor econômico próprio, onde os produtos e serviços oriundos de empreendimentos solidários seriam trocados entre si. Além disso, seria necessária a oferta de crédito em melhores condições para esses empreendimentos. Em outros termos, o que Singer já estava propondo nessa época era a formação de "redes" de economia solidária ou de complexos cooperativos, como as iniciativas que a ADS vem desenvolvendo atualmente. Elas têm buscado fazer com que os produtos e serviços dos empreendimentos solidários articulem-se entre si, visando também o desenvolvimento do local onde se instalam. Essa proposta, contudo, não defende que eles se fechem completamente em um mercado próprio, "paralelo" ao mercado capitalista e "protegido", como lembra Novaes (2011). Isso porque, para Singer e para a ADS, nesse contexto haveria uma positividade na competição dos empreendimentos solidários com o mercado capitalista. De acordo com ele, em momentos de crise, por exemplo, as cooperativas (principalmente de produção) podem se adaptar mais facilmente porque os seus sócios podem aceitar mais facilmente partilhar perdas equitativamente, o que poderia fazer com que elas superassem as empresas capitalistas (SINGER, 1999, p. 113).

Singer não considera essa aceitação tranquila de perdas como sendo uma contradição em relação aos princípios da economia solidária, pois se isso for decidido coletivamente entre os participantes sócios, obedecendo a padrões democráticos, estaria garantido o caráter solidário do empreendimento. Aliás, é a presença desses dois elementos, a democracia interna e a autogestão econômica do empreendimento (isto é, quando 
a organização do trabalho é determinada pelos próprios trabalhadores, sem intervenção "externa") que ele concebe a principal contribuição dos empreendimentos econômico-solidários na realização do modo de produção socialista.

\section{Conclusões}

Isso nos leva a concluir que, olhando do ponto de vista da concepção de construção do socialismo para a CUT (via tese singerista da revolução social), teria havido um compartilhamento dessa luta com a ADS. Enquanto a CUT continuaria tocando as lutas sindicais e trabalhistas burocráticas em permanente negociação com o empresariado e os governos (facilitado, sobretudo, por um contexto econômico nacional que favoreceu melhores reajustes salariais e participação nos lucros, porém sem conseguir reverter os processos de flexibilização do trabalho introduzido nos anos $1990^{\circ}$ ), caberia à ADS também a tarefa de criar as condições "silenciosas" para a implementação da revolução social socialista.

A proposta da CUT, via ADS, com base em Singer, faz a redução da democracia e do controle coletivo da produção aos limites internos dos empreendimentos econômico-solidários, incentivando um tipo de participação que pouco questiona as políticas econômicas fundamentais do Estado e a vinculação dos empreendimentos com o sistema de troca, distribuição e consumo capitalista. Pouco importando a natureza privada ou estatal de um empreendimento solidário, já que bastaria somente que as relações de trabalho fossem democráticas, igualitárias, transparentes e solidárias.

Quando analisadas em conjunto, na perspectiva da organização da classe trabalhadora brasileira, a ação da CUT

8 Reflexões permitidas por KREIN, José Dari; TEIXEIRA, Marilane Oliveira. As controvérsias das negociações coletivas nos anos 2000 no Brasil. In: OLIVEIRA, R. V.; BRIDI, M. A.; FERRAZ, M. (Orgs.) O sindicalismo na era Lula: paradoxos, perspectivas e olhares. Belo Horizonte: Fino Traço, 2014. p. 213-245. 
Nacional (com sua prática cidadã) e a atuação da ADS (com seu sentido de socialismo), somos levados a observar que elas se dão entre dois extremos que se completam e que pouco influem para a tão propalada mudança socialista da sociedade brasileira: de um lado, um "politicismo" porque atrelado às instâncias oficiais (do Estado e do empresariado) e que não busca e é incapaz de promover mudanças econômico-sociais profundas pois atua nos limites dos acordos corporativos consensuais ou possíveis voltados para as principais categorias organizadas sob sua sigla, e, de outro lado, um "economicismo" na organização dos empreendimentos solidários porque eles concorreriam para promover melhorias nas condições materiais de vida de seus associados estritamente através da sua "inclusão" nos mercados, não buscando promover modificações (que não fossem moralistas somente) na estrutura da circulação capitalista e tampouco a intervenção política em processos mais amplos de reprodução social.

\section{Referências}

ABENDROTH, Wolfgang. A história social do movimento trabalhista europeu. Rio de Janeiro: Paz e Terra, 1977.

ALVES, Giovanni. Trabalho e sindicalismo no Brasil dos anos 2000: dilemas da era neoliberal. In: ANTUNES, Ricardo (Org.). Riqueza e miséria do trabalho no Brasil. São Paulo: Boitempo, 2006. p. 461-474.

COGGIOLA, Osvaldo. Os inícios das organizações dos trabalhadores. Aurora, v. 4, n. 6, p. 11-20, ago. 2010.

CONGRESSO NACIONAL DA CUT (CONCUT), 1., São Bernardo dos Campos, 1984. Resoluções. São Paulo: CUT; CEDOC - Centro de Memória e Documentação da CUT, 1984.

CONGRESSO NACIONAL DA CUT (CONCUT), 7., Serra Negra, 2000. Resoluções. São Paulo: CUT; CEDOC - Centro de Memória e Documentação da CUT, 2000. 
DOMINGUES, Marta Regina; TEIXEIRA, Marilaine Oliveira (Orgs.). Metodologia para um índice de desenvolvimento em empreendimentos solidários. São Paulo: CUT, 2007.

ENGELS, Friedrich. Do socialismo utópico ao socialismo científico. São Paulo: Global, 1986.

HEILBRONER, Robert. A história do pensamento econômico. São Paulo: Nova Cultural, 1996. (Coleção Os Economistas).

HOBSBAWN, Eric. História do marxismo. Rio de Janeiro: Paz e Terra, 1983.

KREIN, José Dari; TEIXEIRA, Marilane Oliveira. As controvérsias das negociações coletivas nos anos 2000 no Brasil. In: OLIVEIRA, R. V.; BRIDI, M. A.; FERRAZ, M. (Orgs.) O sindicalismo na era Lula: paradoxos, perspectivas e olhares. Belo Horizonte: Fino Traço, 2014. p. 213-245.

MARX. São Paulo: Nova Cultural, 2005. (Coleção Os Pensadores).

MARX, Karl. Manifesto de lançamento da Associação Internacional dos Trabalhadores. In: MARX, Karl; ENGELS, Friedrich. Texto 2. São Paulo: Edições Sociais, 1977.

MARX, Karl; ENGELS, Friedrich. O manifesto comunista. Rio de Janeiro: Paz e Terra, 2002.

PLENÁRIA NACIONAL DA CUT, 10., São Paulo, 2002. Resoluções. São Paulo: CUT, 2002.

SANDRONI, Paulo (Org.). Novíssimo dicionário de economia. São Paulo: Best Seller, 1999.

SCHEIDER, José Odelso. Democracia, participação e autonomia cooperativa. São Leopoldo: Unisinos, 1999. 
SINGER, Paul. Introdução à economia solidária. São Paulo: Fundação Perseu Abramo, 2002.

SINGER, Paul. Uma utopia militante: repensando o socialismo. 2. ed. Petrópolis: Vozes, 1999.

TEIXEIRA, Aloisio. Utópicos, heréticos e malditos: os precursores do pensamento social de nossa época. Rio de Janeiro: Record, 2002.

Recebido em abril de 2016. Aprovado em janeiro de 2017. 